\title{
Mineral shock signatures in rocks from Dhala (Mohar) impact structure, Shivpuri district, Madhya Pradesh, India
}

\author{
Madhuparna Roy*, Pradeep Pandey, Shailendra Kumar \\ and P S PARIHAR \\ Atomic Minerals Directorate for Exploration and Research, Department of Atomic Energy, New Delhi \\ 110 066, India. \\ *Corresponding author.e-mail: madhuparnaroy.amd@gov.in
}

MS received 13 October 2016; revised 25 May 2017; accepted 26 May 2017; published online 23 November 2017

A concrete study combining optical microscopy, Raman spectroscopy and X-ray diffractometry, was carried out on subsurface samples of basement granite and melt breccia from Mohar (Dhala) impact structure, Shivpuri district, Madhya Pradesh, India. Optical microscopy reveals aberrations in the optical properties of quartz and feldspar in the form of planar deformation feature-like structures, lowered birefringence and mosaics in quartz, toasting, planar fractures and ladder texture in alkali feldspar and near-isotropism in bytownite. It also brings to light incidence of parisite, a radioactive rare mineral in shocked granite. Raman spectral pattern, peak positions, peak widths and multiplicity of peak groups of all minerals, suggest subtle structural/crystallographic deviations. XRD data further reveals minute deviations of unit cell parameters of quartz, alkali feldspar and plagioclase, with respect to standard $\alpha$ quartz, high- and low albite and microcline. Reduced cell volumes in these minerals indicate compression due to pressure. The $c_{0} / a_{0}$ values indicate an inter-tetrahedral angle roughly between $120^{\circ}$ and $144^{\circ}$, further pointing to a possible pressure maxima of around $12 \mathrm{GPa}$. The observed unit cell aberration of minerals may indicate an intermediate stage between crystalline and amorphous stages, thereby, signifying possible overprinting of decompression signatures over shock compression effects, from a shock recovery process.

Keywords. Dhala (Mohar) impact structure; shock signature; optical microscopy; Raman spectroscopy; X-ray diffractometry; parisite.

\section{Introduction}

The circular structure at Mohar $\left(25^{\circ} 18.228^{\prime}\right.$ : $78^{\circ} 09.194^{\prime}$; Survey of India toposheet no. $54 \mathrm{~K} / 3$ ), also known as Dhala impact structure, Shivpuri district, Madhya Pradesh, in the western part of Bundelkhand Gneissic Complex, was interpreted as a volcanic cauldron structure (Jain et al. 2001) and meteoritic impact crater structure (Pati et al. 2005, 2008), on the basis of absence or presence of shock indicators, respectively, in the clasts of a rhyolite-like rock that crops out scantily around the structure. During the course of subsurface uranium exploration in this structure, the geoscientists of Atomic Minerals Directorate for Exploration and Research observed the presence of voluminous melt rock (melt breccia) beneath the mesa, which is the surface manifestation of the structure. Petrological study of drill core samples brought to light unequivocal and rampant evidences of 

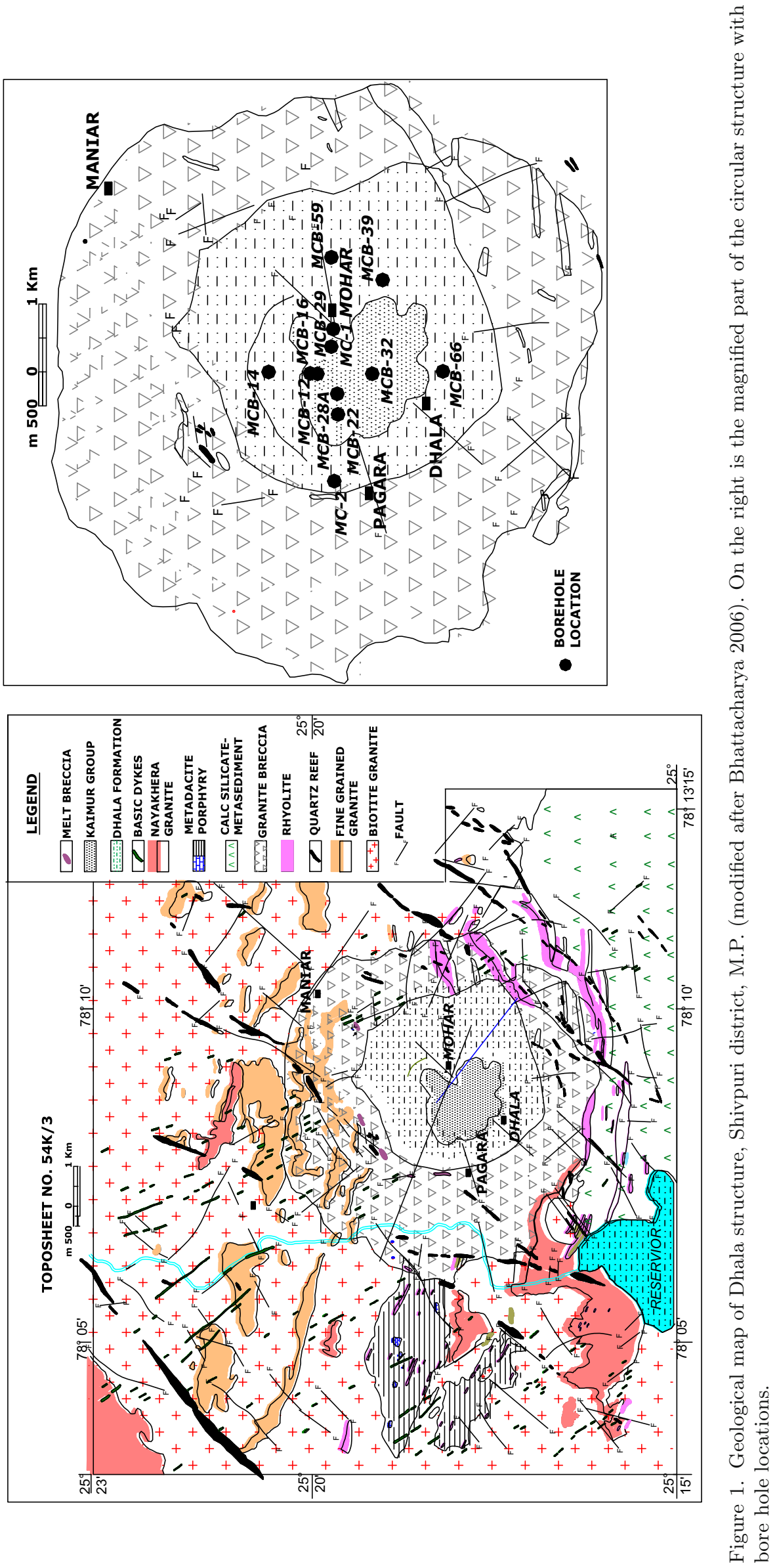
shock metamorphic features in the melt breccia as well as the basement granitoids underlying it (Roy et al. 2014). The shock metamorphic features comprise planar deformation features (PDF)-like structures in quartz, feldspar, apatite and zircon, toasted, diaplectic, ladder-textured feldspars, selectively shock-melted feldspars, ballen quartz and melt-veined quartz. Pronounced aberrations were noted in the optical properties of common rock forming silicates in the form of discolouration of grains, development of fractures, lowering of birefringence resulting in anomalous interference colour, shock mosaics and isotropism of grains, melt veining, grain vesiculation besides pronounced deformation of grains. Recently, micro-Raman signatures of quartz and feldspars also revealed high degree of irregularities due to shock damage (Roy 2017). All this warranted mineralogical studies by various tools, in order to document shock deformation in rock forming minerals. In this paper, the optical-, micro-Raman spectroscopic- and Xray diffractometry data on minerals are presented for the understanding of shock effect on rock forming minerals.

\section{Geology}

The Dhala (Mohar) circular structure (Dhala structure, Pati 2005, 2008; Mohar structure, Roy 2014) located in the western part of Bundelkhand Craton comprises mainly Archaean and Paleoproterozoic rocks referred to as Bundelkhand Gneissic Complex (BGC), unconformably overlain by the sediments of Meso- to Neoproterozoic Vindhyan Supergroup. The BGC is dominated by Bundelkhand granitoids together with minor enclaves of older metamorphic supracrustals comprising metasediments, metavolcanics, rocks of TonaliteTrondjhemite-Granodiorite (TTG) affinity, mafic and ultramafic rocks (Basu 1986; Mondal et al. 2002). It is traversed by quartz reefs and dolerite dyke swarms. The Dhala (Mohar) structure (figure 1) is noticeable due to the conspicuous presence of a $4.5 \mathrm{~km}$ diameter mesa of sedimentary rocks, protruding up by about $100 \mathrm{~m}$, above a backdrop of concentric annular ring-like outcrops of sediments of Dhala Formation (pre-Kaimur) outwardly followed by prominent hummocky granite breccia (Jain et al. 2001; Pati et al. 2008; figure 2).

The lithology of the structure is established on the basis of extensive surface and subsurface studies, carried out by AMD, during the

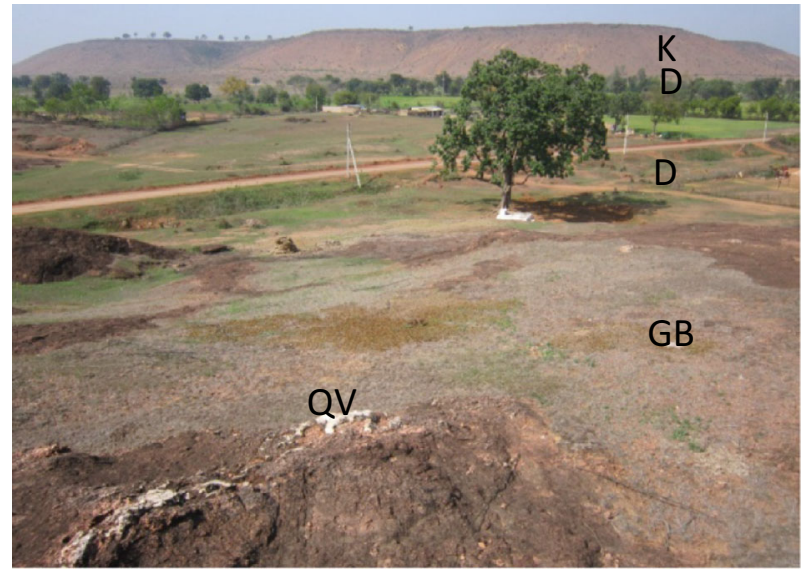

Figure 2. The near-circular mesa-like structure. (K: Kaimur Group; D: Dhala Formation; GB: Granite breccia; QV: Quartz vein).

course of exploration. The lithologic succession comprises basement Bundelkhand granite overlain by melt breccia of variable thickness. This is unconformably overlain by shale-siltstone of Dhala Formation and sandstone of Kaimur Group (Vindhyan Super Group). The melt breccia, occurring as sparse isolated outcrops around the structure, is an extremely heterogeneous pink to brick red, vesicular to non-vesicular tuff-like rock, having an extremely variable thickness (up to about $200 \mathrm{~m}$ in the central part of the structure), below the sedimentary cap. Few pockets of it are also noted within the basement granite at depth, indicating that the melt pockets were formed at the time of impact. The disposition of different litho units within the structure can be envisaged from strip logs along $\mathrm{E}-\mathrm{W}$ and $\mathrm{N}-\mathrm{S}$ section across the structure (figure $3 \mathrm{a}, \mathrm{b}$ ). It is established from the subsurface data that the structure, with a $7.5 \mathrm{~km}$ diameter, is that of a simple crater without a central uplift, as no granitic basement rocks have been intercepted at shallow depths in any of the boreholes drilled at the center of the mesa. The basement granite as well as the melt breccia bear signatures of shock metamorphism, with the latter possibly having been derived by the shock melting of the former (Roy et al. 2014).

\section{Methodology}

Integrated study was carried out on borehole core samples from Dhala (Mohar) structure to understand the mineralogy of the basement granite and melt breccia, with the aid of optical 


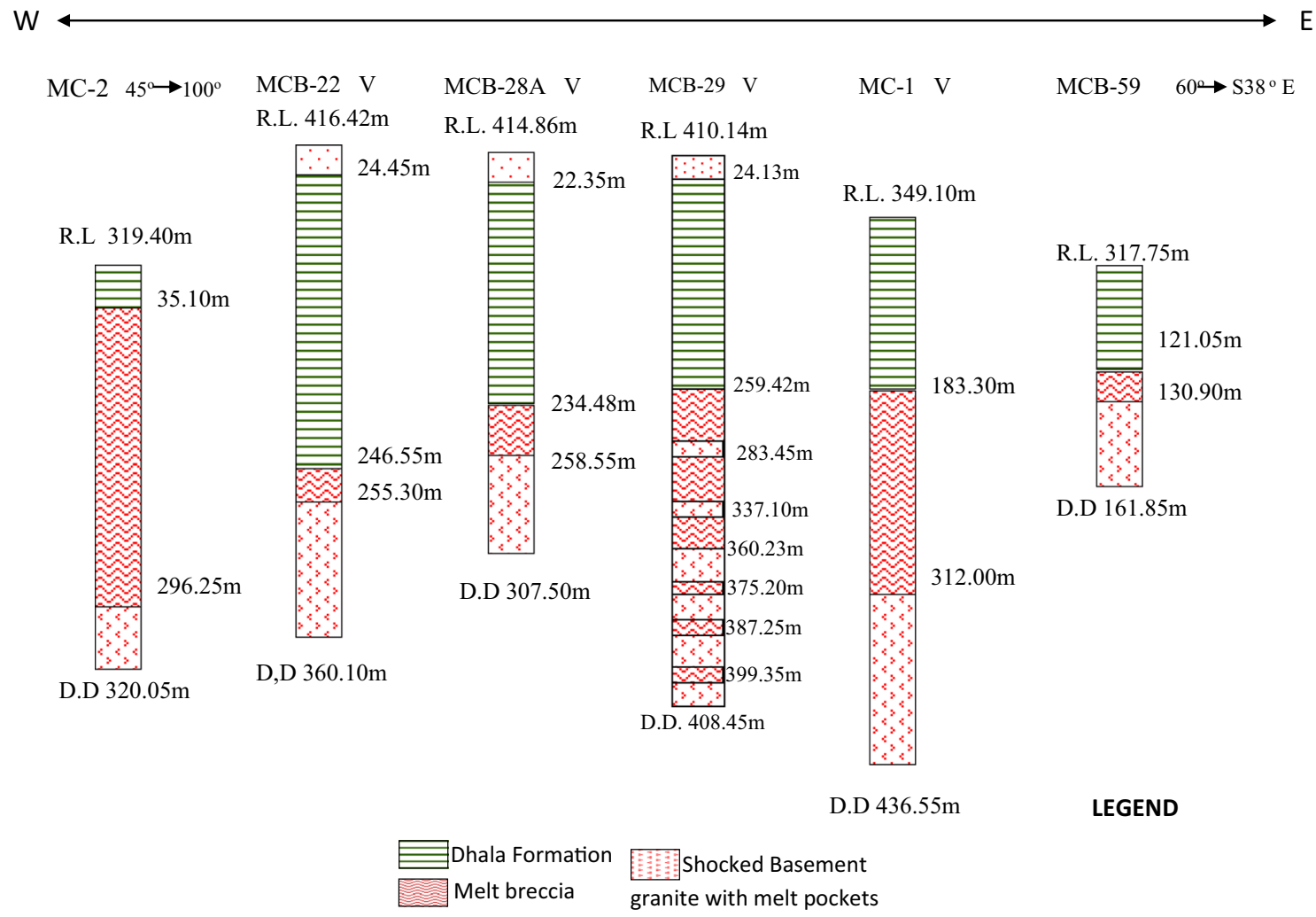

(a)

$\mathrm{S}$

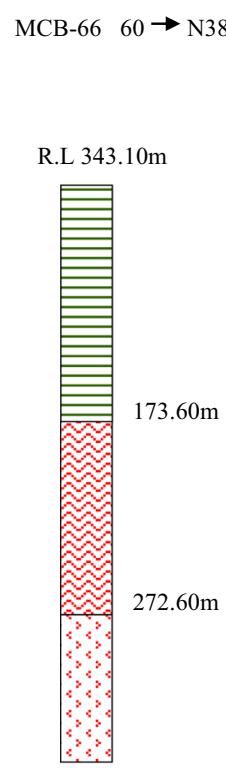

D.D $319.40 \mathrm{~m}$

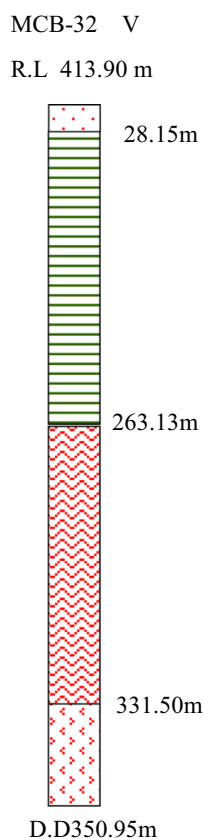

MCB-16 V

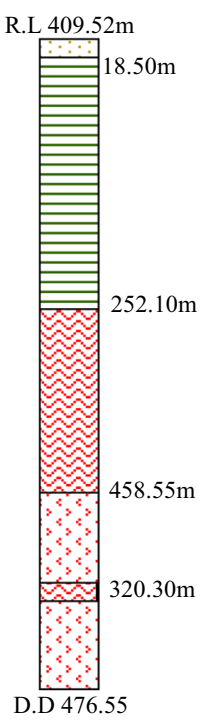

(b)
MCB-12 V MCB-14 V

R.L $407.00 \mathrm{~m}$

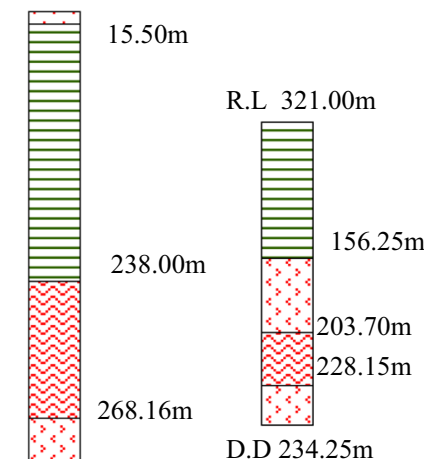

$314.10 \mathrm{~m}$

D.D $322.49 \mathrm{~m}$

Figure 3. (a) Striplog (not to scale) of MC-2, MCB-22, MCB-28A, MCB-29, MC-1 and MCB-59 along E-W showing different lithounits in core column. (MC-1,2 were drilled by GSI; others by AMD), (b) Striplog (not to scale) of MCB-66, MCB-32, MCB-16, MCB-12 and MCB-14 along N-S showing different lithounits in core column. DD is drilled depth and V is vertical bore hole). 


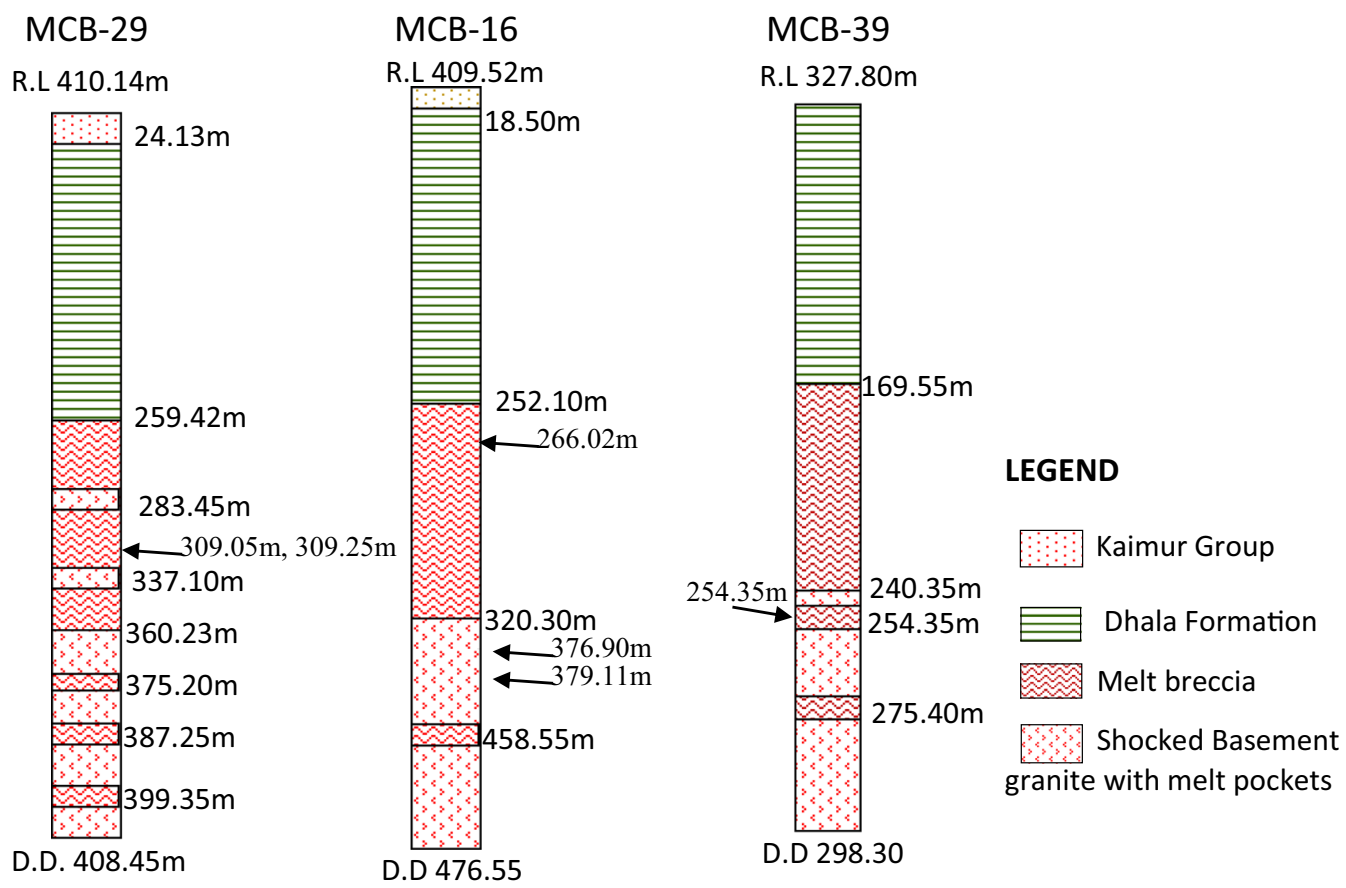

Figure 4. Striplogs (not to scale) of vertical bore holes MCB-16, MCB-29 and MCB-39 showing different lithounits in core column. Black arrow denotes depths of studied samples. DD is drilled depth.

microscopy, Micro Raman spectrography and X-ray diffractometry. The strip log of the boreholes, from which samples were studied are represented in figure 4. Optical microscopy was carried out under Nikon polarized light microscope. Micro Raman spectroscopy on selected minerals, was performed on uncovered thin sections of rock. The Horiba JY HR Lab Ram laser micro Raman spectrometer used for this purpose at Wadia Institute of Himalayan Geology, Dehradun, is fitted with 514.4 and $785 \mathrm{~nm}$ lasers, 600 and $1800 \mathrm{~mm}$ lines grating, multichannel CCD detector and confocal optics. The 514.4 nm exciting line of Spectra Physics $\mathrm{Ar}^{+}$laser was focused on the samples through Olympus BX41 microscope with a laser beam diameter of $<2 \mu \mathrm{m}$ at $100 \times$ objective. Silicon standard was used in the calibration of the instrument and the spectral resolution of the instrument is $1-2 \mathrm{~cm}^{-1}$. Data management is through LabSpec 5 software. X-ray diffractometry was carried out with the help of Siefert Id 3000-Xray generator and Siemens microprocessor controlled D-500 diffractometer system, using crystal monochromated characteristic $\mathrm{CuK} \alpha$ radiation and LA 100 recorder. X-ray diffraction (XRD) study on powdered whole rock samples was carried out in Siemens D-500 diffractometer. The accelerating voltage was maintained at $35 \mathrm{kV}$ and the tube current at $22 \mathrm{~mA}$. CuK $\alpha$ radiation (1.5418 $\AA)$ was used and curved graphite constituted the monochromator. For identification, a scanning speed of 0.03 degrees $2 \Theta$ /second, over a long angular range, with a sampling time of 2 sec, was selected. Mineral identification was done from the powder diffraction data obtained and matching the same with the relevant International Centre for Diffraction Data (ICDD) card.

\section{Results}

\subsection{Optical microscopy}

Optical microscopy and petrological study was carried out on samples from basement granite and melt breccia. The findings are discussed below.

\subsubsection{Basement granite}

It is generally shocked, with rusty red feldspar and chalky white opaque quartz in the bore hole cores (figure 5a) and is microscopically characterized by highly deformed feldspars (figure 5b) and a wide variety of shock metamorphic features that leave indelible marks on quartz, feldspar, biotite, zircon and apatite (Roy et al. 2014). The rock comprises medium grains of highly deformed, dark red, toasted feldspars, quartz with rampant 


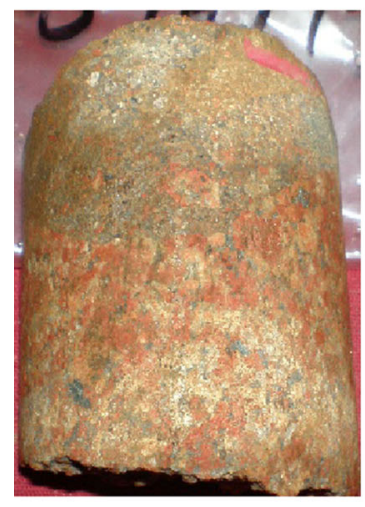

(a)

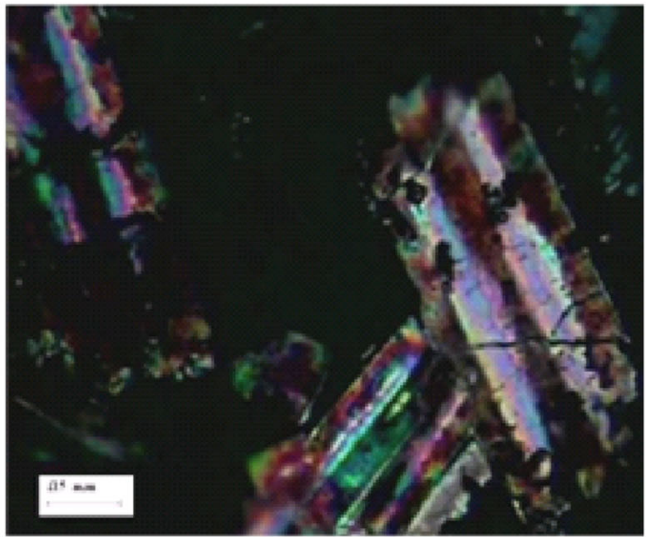

(d)

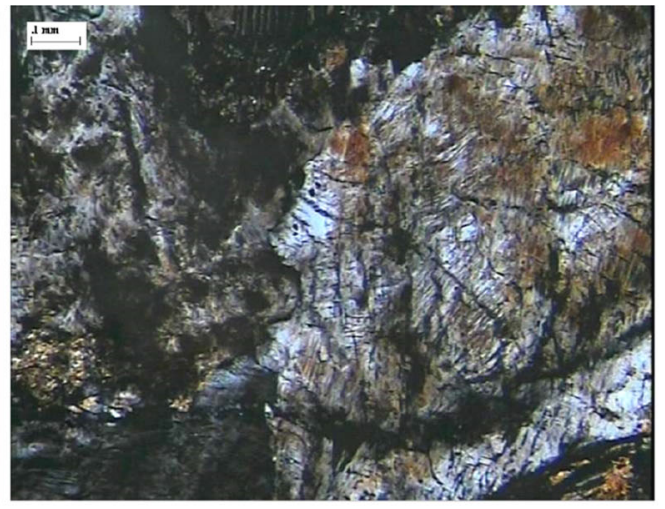

(b)

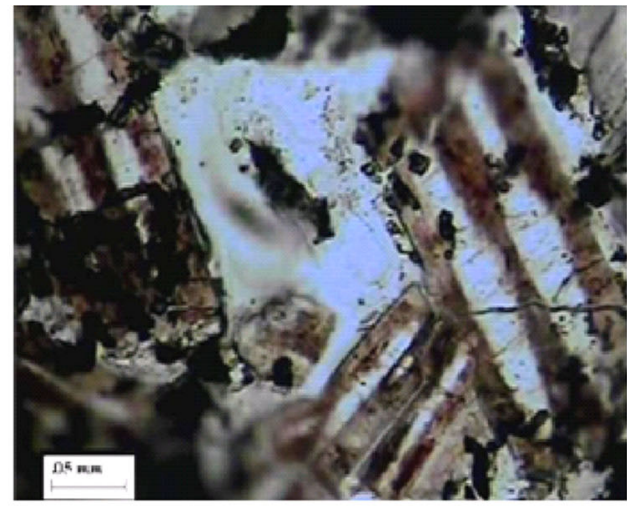

(c)

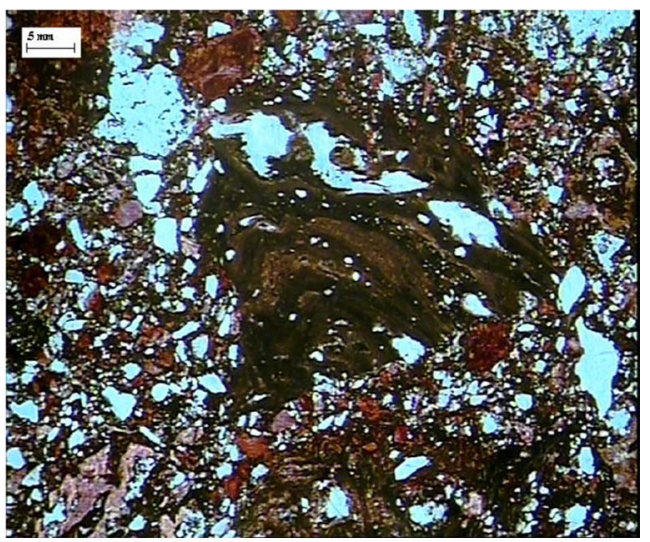

(f)

Figure 5. (a) View of core sample of shocked basement granite. Note contact with melt breccia at the top. (b) Deformed feldspar in shocked granite. Trans. Light, 1Nicol, air, bar $=0.1 \mathrm{~mm}$. (c) Accessory parisite with lamellae/striation in shocked granite (confirmed by Raman Spectroscopy), Trans. Light, 1 Nicol, air, bar $=0.05 \mathrm{~mm}$. (d) The same mineral under crossed Nicols. (e) View of core sample of melt breccia. (f) Chaotic assemblage of clasts, glass schlieren (dark brown) and felsic groundmass (red) constituting melt breccia. Trans. Light, 1Nicol, air, bar $=0.5 \mathrm{~mm}$.

planar deformation features (PDF)-like structures, heterogeneous anisotropism or melt veining, biotite/chlorite showing kink banding and accessory zircon and apatite exhibiting planar deformation feature. The feldspar grains often exhibit lowered birefringence, anomalous interference colour, ladder textures and planar/non-planar fractures. Many feldspar grains are diaplectic and also show signs of vesiculation, core melting and centre-toperiphery plastic flowage, indicating conditions of extreme shock. Quartz grains are also marked by very low birefringence and highly undulose extinction, often exhibiting planar/non-planar, radiating fractures, in addition to PDF-like structures and in cases of extreme shock, develop reticulate melt veins. In addition to the rock forming minerals, an optically indeterminable transparent, subhedral, accessory mineral (figure 5c) is found to occur in clusters within the interstice of green biotite, shocked quartz and toasted feldspar. This mineral is marked by conspicuous brown lamellae/ striations, very high interference colour (figure 5d) in the transparent portion and gives very low density alpha tracks on $\mathrm{CN}-85$ film exposed for seven days.

\subsubsection{Melt breccia}

This unit comprises of highly heterogeneous rocks containing varying proportion of green to red groundmass, clasts of rocks and minerals, as well as glass schlieren/fiamme, as observable in core samples (figure 5e). Both vesicular and non-vesicular varieties of melt rocks are present. The groundmass of the melt breccia is composed of red or green glassy material or microcrystalline feldspar aggregate and the latter composed of poorly sorted shocked/unshocked fragments of quartz, feldspar, 


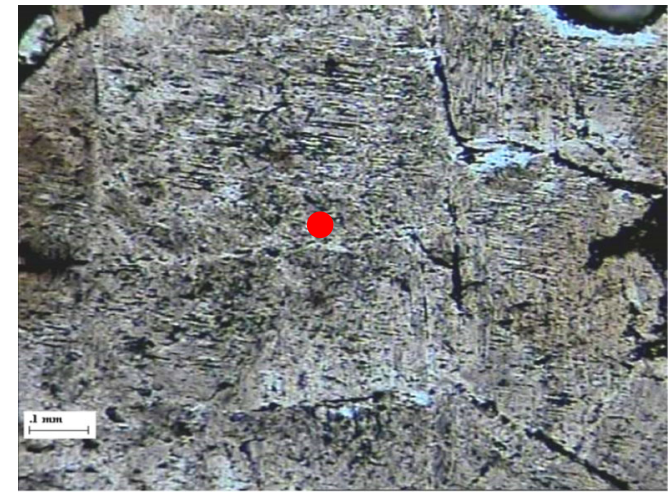

(a)

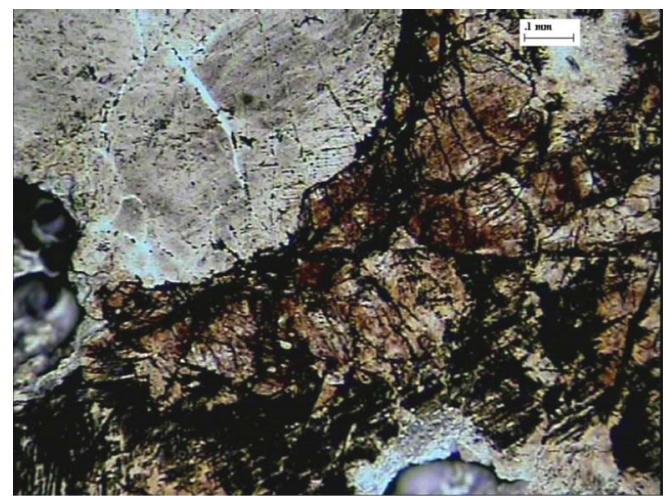

(c)

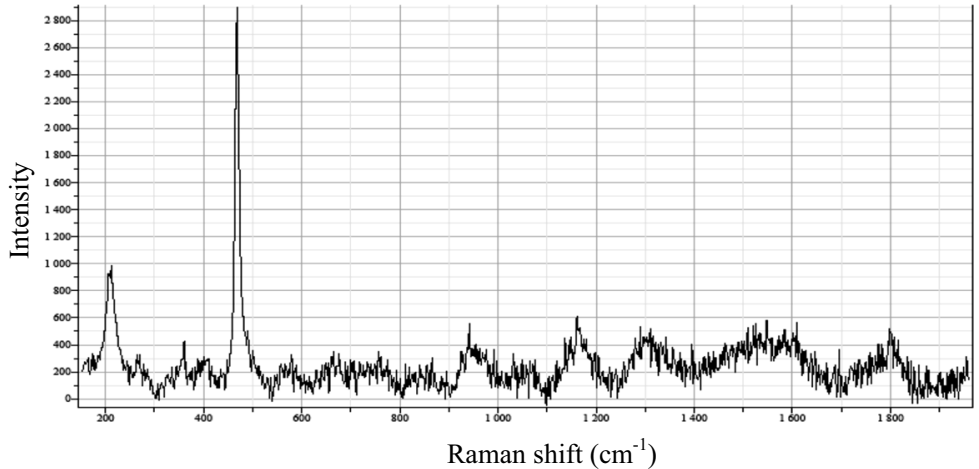

(b)

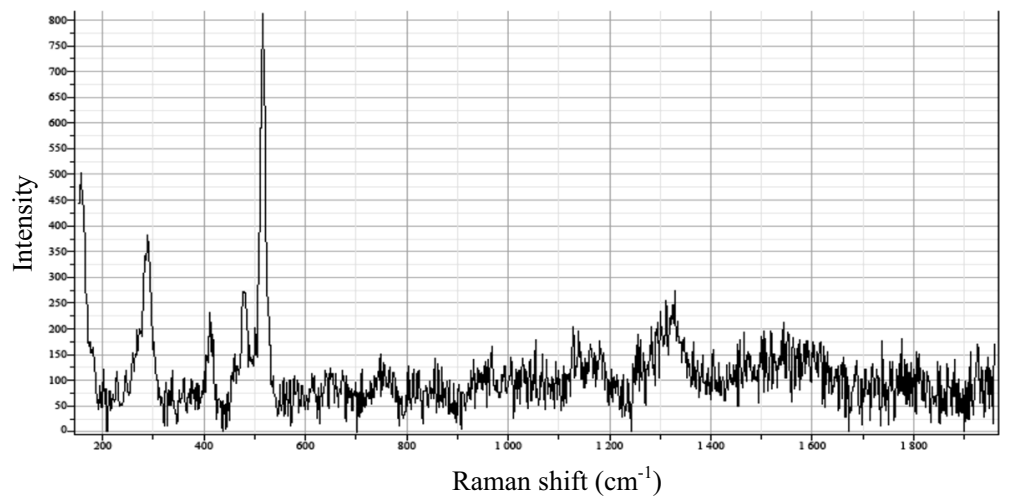

(d)

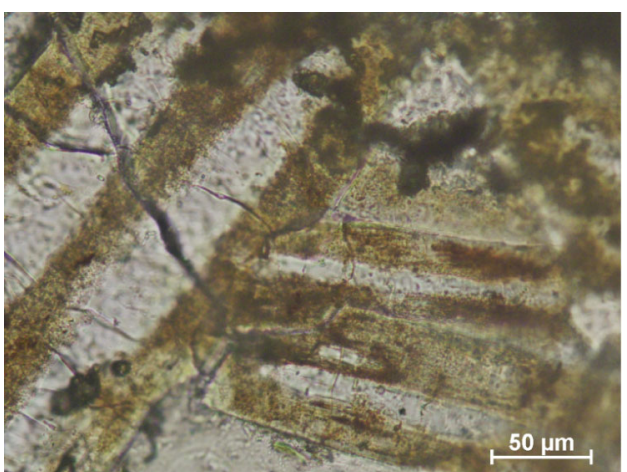

(e)

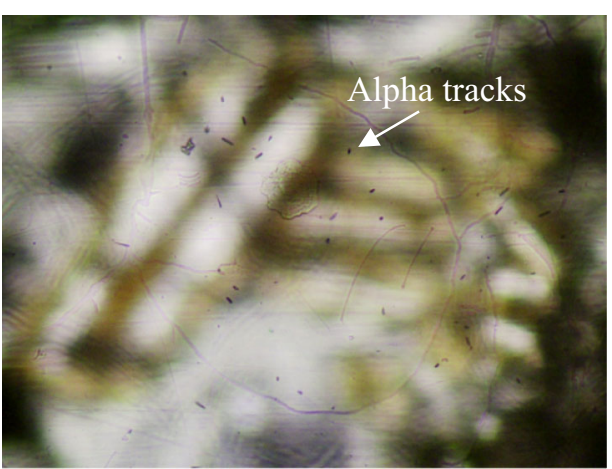

(f)

Figure 6. (a) Photomicrograph of quartz with PDF. Bar: $0.1 \mathrm{~mm}$. (b) Corresponding Raman spectra in the right. (c) Photomicrograph of toasted K-feldspar. Bar: $0.1 \mathrm{~mm}$. (d) Corresponding Raman spectra in the right. (e) Magnified photomicrograph of parisite showing striations, Trans. light, 1N, air. (f) Sparse alpha tracks (fine black dots) on CN-85 film to indicate weak radioactivity, Trans. light, $1 \mathrm{~N}$. (g and $\mathbf{h}$ ) Magnified part of transparent part and dark striation respectively. Red is the probe spot, Trans. light, 1N. (i and $\mathbf{j}$ ) Raman spectra of transparent part and dark striation.

granite rock fragments, basic rock fragments and glass schlieren (figure $5 \mathrm{f}$ ). The groundmass often exhibits flow texture as it entrails randomly oriented fragments or primary vesicles along the flow. Occasionally, it contains evidence of carbonatesilicate melt immiscibility (Roy 2016). The shock signatures in the fragments include PDF-like structure and mosaics in quartz, toasted and ladder-textured feldspars, near isotropised, diaplectic quartz and feldspars, grape-like Ballen quartz, kink-banded biotite/chlorite and shock isotropised bytownite bearing erstwhile altered mafic rock. 


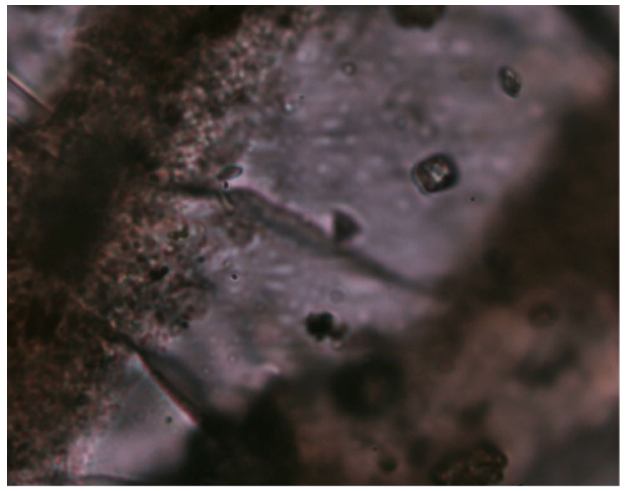

(g)

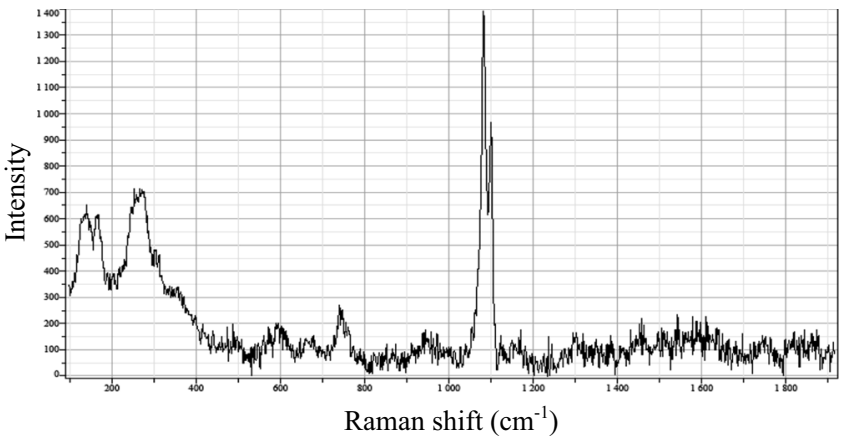

(i)

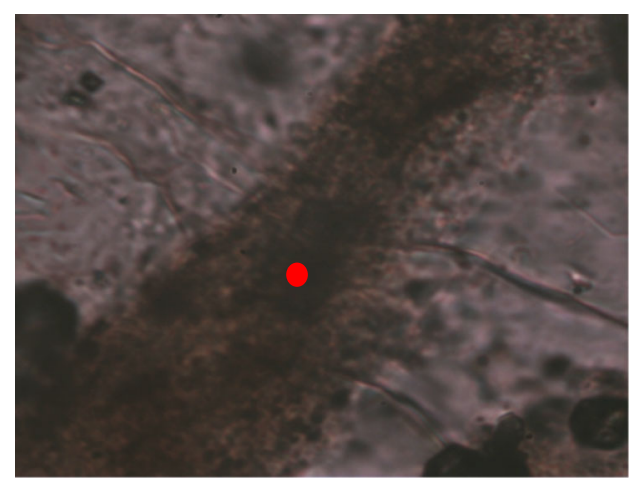

(h)

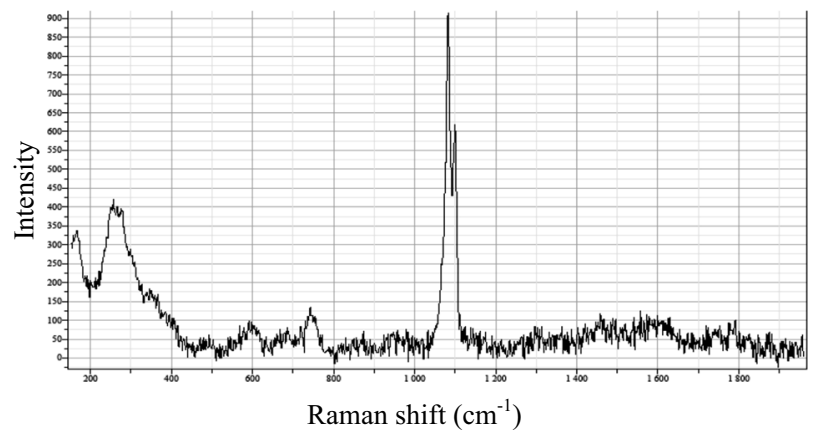

(j)

Figure 6. (Continued.)

\subsection{Micro Raman spectroscopy}

Micro Raman spectroscopic study was carried out on selected samples from basement granite and melt breccia. The minerals from basement granite includes quartz exhibiting multiple PDFlike structure and reddish brown toasted feldspar.

\subsubsection{Basement granite}

The spectra of quartz (with PDF-like structure), toasted feldspar and parisite (sample no. MCB$29 / 309.05$ ) are shown in figure 6. The spectra of quartz with PDF (figure 6a, b) matches well with standard $\alpha$-quartz (Raman shift peaks at 205, $464 \mathrm{~cm}^{-1}$ ) and that of toasted feldspar (figure 6c, d) with standard orthoclase (Raman shift peak around $514 \mathrm{~cm}^{-1}$ with prominent triplet between 450 and $515 \mathrm{~cm}^{-1}$ ). However, minor aberration noted in case of quartz is that the standard peak of $800 \mathrm{~cm}^{-1}$ is missing in the studied grain, whereas an extra peak is observed at $1300 \mathrm{~cm}^{-1}$. In case of orthoclase, small additional peaks are observed around 1300 and $1500 \mathrm{~cm}^{-1}$ in the studied grain. The optically indeterminable transparent subhedral mineral (figure 6e) that is weakly radioactive (figure 6f) and occurrs as accessory constituent in the shocked granite, is identified as Parisite (a fluorocarbonate of $\mathrm{Ca}$ and $\mathrm{Ce}$ ), as per Raman spectral pattern. It is notable that the transparent part (figure $6 \mathrm{~g}$ ) and the brown striation (figure 6h) are characterised by spectra (figures $6 \mathrm{i}, \mathrm{j}$ respectively) that do not show any noticeable difference, indicating a uniformity in composition, matching closely with that of standard parasite spectral pattern. However, the spectra deviates from the published data (mindat.org) in having a sharp drop of Raman shift from $300-400 \mathrm{~cm}^{-1}$ and thereby deviod of a gentle peak at $400 \mathrm{~cm}^{-1}$ as observed in the published data. An additional small peak is observed in the sample around $670 \mathrm{~cm}^{-1}$. These may be due to lattice distortion attributable to shock damage.

\subsubsection{Melt breccia}

A pale green mafic fragment (3 $\mathrm{mm}$ across) embedded in a red felsic glassy groundmass of the melt breccia was the subject of analysis. The clast, under the naked eye (figure 7a; sample no. MCB-39/254.35) is composed of off-white fine lath shaped minerals associated with green altered 


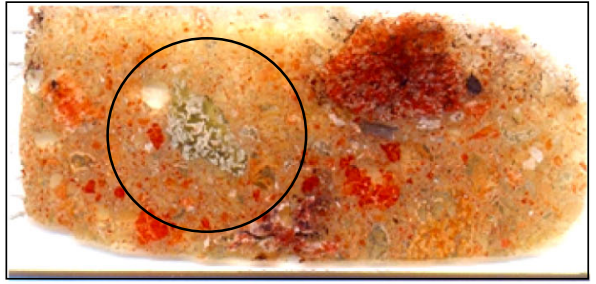

(a)

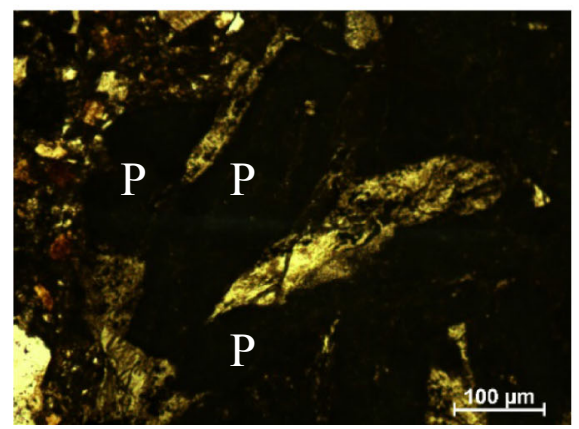

(c)

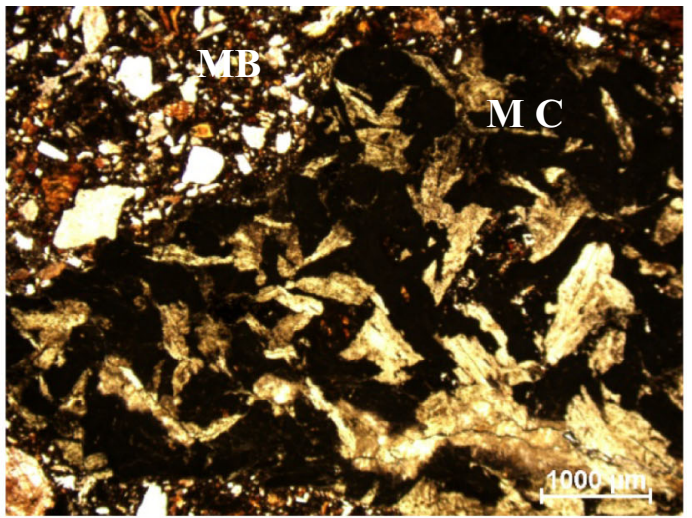

(b)

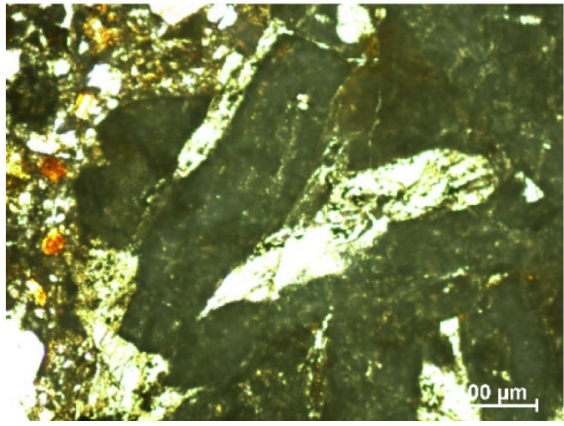

(d)

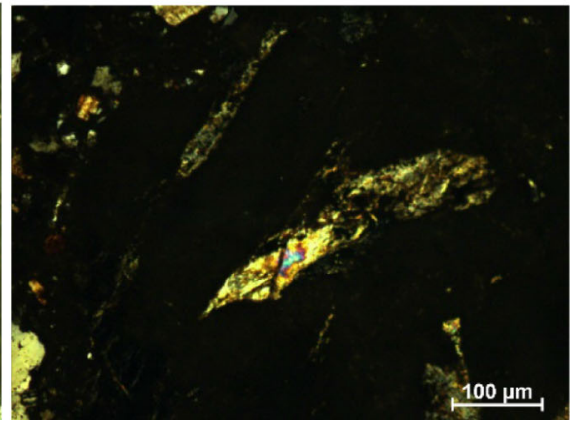

(e)

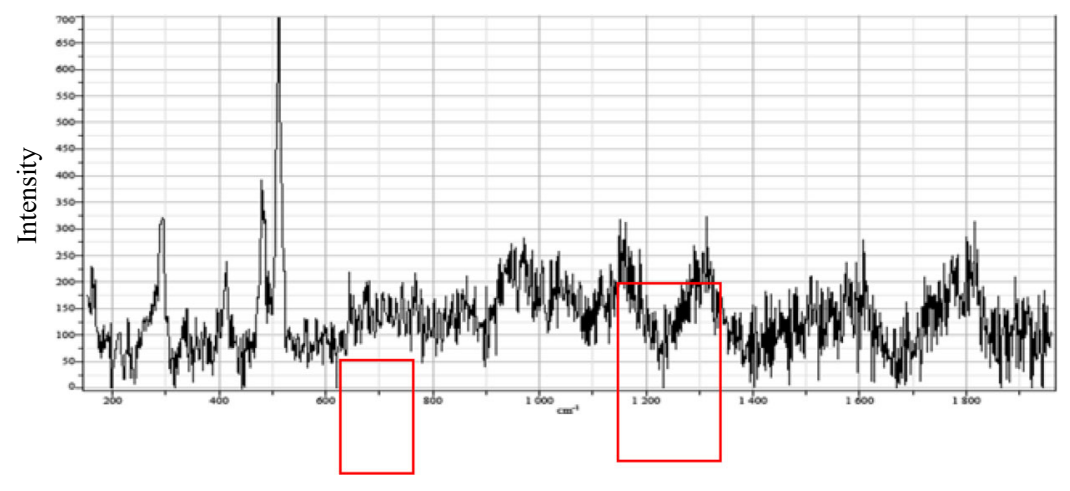

Raman shift $\left(\mathrm{cm}^{-1}\right)$

(f)

Figure 7. (a) View of scanned thin section of melt breccia. Mafic clast shown within frame. (b) Photomicrograph of part of mafic clast (MC) in melt breccia (MB). Trans. light, air, 1N. (c) Photomicrograph of shocked plagioclase laths (P) within mafic clast. Note dark colour under 1N. (d) Same photomicrograph showing inhomogeneity in back-lit view. (e) Same photomicrograph showing near isotropism under XN. (f) Raman spectra of analysed bytownite. Red frame highlights aberration from standard bytownite.

minerals. Microscopically, the mafic clast (figure $7 \mathrm{~b}-\mathrm{e}$ ) is composed of dark brown partially isotropic to weakly anisotropic and non-uniformly birefringent laths. Optical identification of this mineral was difficult due to obliteration of primary optical properties. Micro Raman analysis of the mineral (figure $7 \mathrm{f}$ ) characterised it as bytownite (highly calcic plagioclase). It is notable that although standard spectrum of bytownite is broadly comparable with bytownite of the studied sample, there are noticeable aberrations, viz., peak broadening around Raman shift of $700 \mathrm{~cm}^{-1}$ and development of a peak between 1200 and $1300 \mathrm{~cm}^{-1}$. 


\section{$4.3 X$-ray diffractometry}

The minerals identified by X-ray diffraction (XRD) method in the melt breccia as well as the shocked basement granite are quartz, albite, microcline, biotite, hornblende, chlorite, apart from traces of calcite, galena, sphalerite and chalcopyrite. The crystallographic parameters of quartz and feldspars of a few samples are presented in table 1 .

It is noted that $a_{0}, c_{0}$ and cell volume of the analyzed quartz from shocked granite, are close to that of $\alpha$-quartz ( $a_{0}$ is less than and $c_{0}$ is comparable or slightly greater than that of $\alpha$-quartz). In melt breccia, however, $a_{0}$ of quartz is greater than and $c_{0}$ and cell volume are lesser than that of $\alpha$-quartz. The $c_{0} / \mathrm{a}_{0}$ ratio $(n=4)$ in the shocked granite varies from 1.0996 to 1.1004 and the cell volume varies between 112.9071 and $112.9431 \AA^{3}$, being clearly less than that of $\alpha$-quartz. For $\alpha$ quartz, the silica tetrahedral structure are strictly regular $\left(\mathrm{Si}-\mathrm{O}-\mathrm{Si}\right.$ angle of quartz is $\sim 144^{\circ}$ ) if $\mathrm{c}_{0} / \mathrm{a}_{0}$ is $<1.098$. This ratio increases with pressure and when $\mathrm{c}_{0} / \mathrm{a}_{0}$ becomes $>1.14$ the inter-tetrahedral angle decreases to $<120^{\circ}$ (Deer et al. 2004). This indicates that (i) the silica tetrahedral structure in the present case is not strictly regular and (ii) with $\mathrm{c}_{0} / \mathrm{a}_{0}$ ratio ranging $1.0996-1.1004$ (with error ranging between $\pm 2 \times 10^{-6}$ and $\pm 55 \times 10^{-6}$ ), the inter-tetrahedral angle lies between $120^{\circ}$ and $144^{\circ}$. From the comparison of $\mathrm{c}_{0} / \mathrm{a}_{0}$ with pressure worked out by Angel et al. (1997), high pressure experimental data on gem-quality single crystals of twin-free natural quartz), which documents pressure variation with $c_{0} / a_{0}$, the four sample points (MCB 16/266.02, 376.90, 379.11; MCB 29/309.25) cluster near $\mathrm{c}_{0} / \mathrm{a}_{0}$ values of 1.1 (figure 8 ). But this does not apparently corroborate the optical presence of PDF-like structures in quartz which is believed to be formed at pressures 8-25 GPa (French 1998). Thus, there is some mechanism that is instrumental in the formation of PDF-like structures in quartz, but subsequently erasing all other signatures associated with the shock load that caused the PDFs to appear. Kingma et al. (1993), using in situ X-ray diffraction, Raman scattering and optical microscopy, studied $\alpha$-quartz at high pressure and found that a new phase transformation occurs at $21 \mathrm{GPa}$, which on decompression, reverts to a quartz-like structure which is now in the form of a mixture of crystals with an increasing proportion of amorphous silica, as the pressure increases beyond $21 \mathrm{GPa}$. This may explain why quartz grains that bear PDF-like

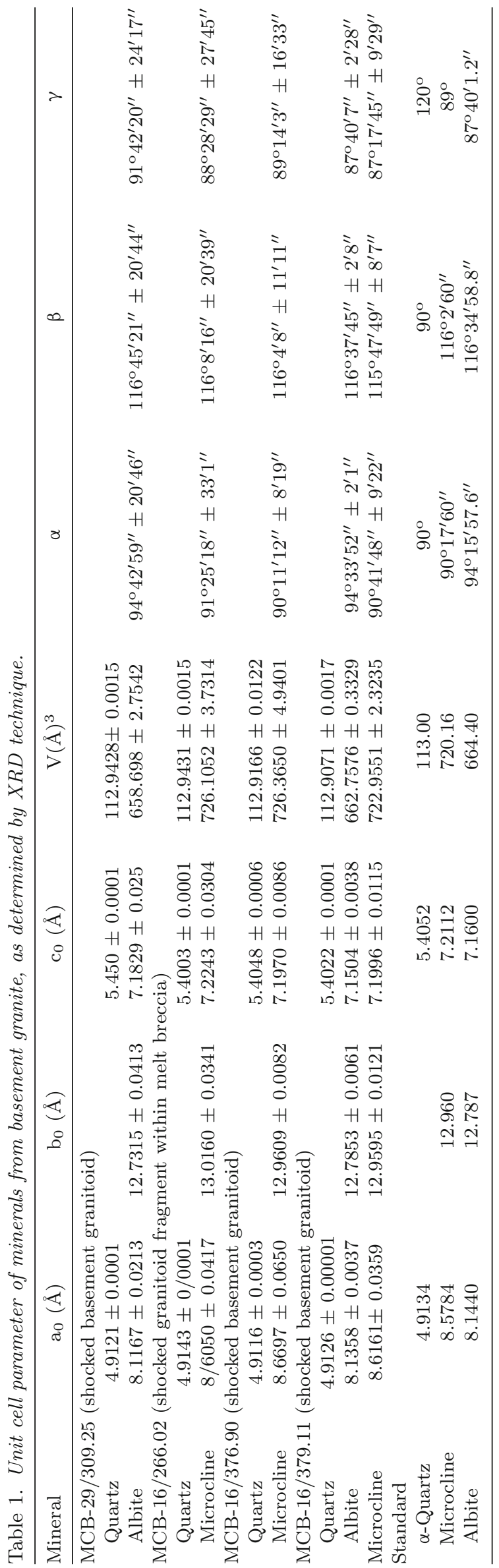




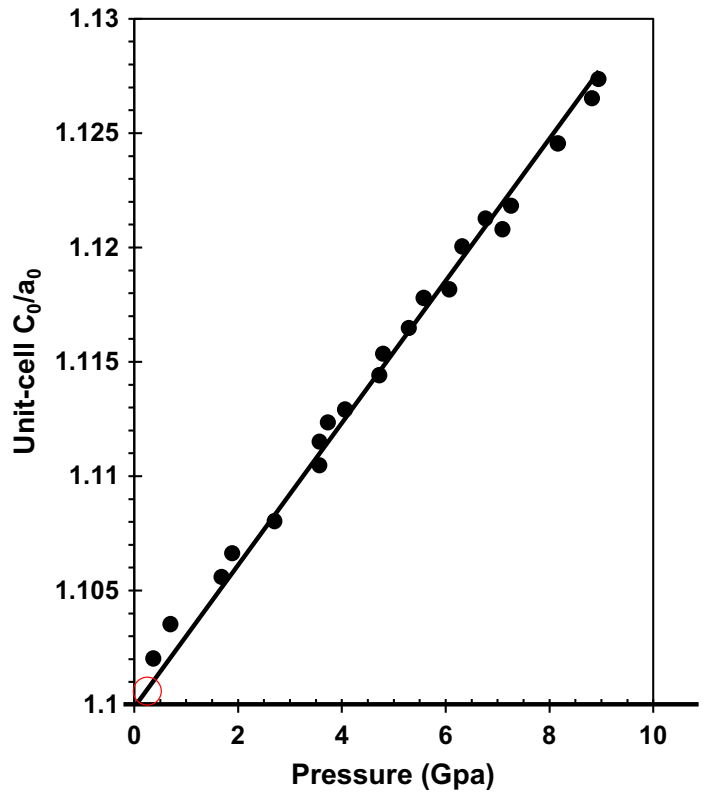

Figure 8. Sample plots (red) on unit-cell $c_{0} / \mathrm{a}_{0}$ vs. Pressure diagram of Angel et al. (1997). Angel's samples are represented by dots.

structures, do not retain crystallographic signatures of the high pressure that caused it, due to the preponderance of an amorphous phase of silica during decompression. Huffman et al. (1993) and others provided strong evidences of amorphisation of quartz in a solid state. This also explains the anomalously low birefringence of quartz exhibiting PDF-like structures, implying variable degree of decompression-induced amorphisation. Other researches like Somayazulu et al. (1994) similarly indicated a precursor phase prior to amorphisation through molecular dynamics. This is supported by NMR spectra studies of shocked quartz which indicates increasing amounts of amorphous phase of silica at pressures $>25 \mathrm{GPa}$.

For albite from shocked granites, $\mathrm{a}_{0}$ and $\mathrm{b}_{0}$ are less and $c_{0}$ is greater than that of normal high albite (Deer et al. 2001) whereas $\mathrm{a}_{0}$ and $\mathrm{b}_{0}$ are equal/less than, and $c_{0}$ is greater or lesser than that of low albite (Deer et al. 2001). The volumes of the unit cell $\left(658.70,662.76 \AA^{3}\right)$ are close to $663.1 \AA^{3}$, which is the normal volume at 1 atm and slightly greater than $651.1 \AA^{3}$ which is the normal volume at $11 \mathrm{~atm}$ (Hazen and Prewitt 1977). $\alpha$ and $\beta$ are greater than that of both high and low albite, whereas $\gamma$ is either greater or lesser than that of high and low albite. For microcline from both breccia and shocked granitoid, $\mathrm{a}_{0}$ is greater than that of low microcline. The $\mathrm{b}_{0}$ and $\mathrm{c}_{0}$ are less than that of low microcline in shocked granite, but greater in the breccia. The $\alpha, \beta$, and $\gamma$ are either less or more than that of low microcline for all the samples.

\section{Discussion}

The combined approach of optical microscopy, Micro Raman spectroscopy and XRD technique helps to understand signatures of shock, etched on the rock forming minerals from melt breccia and basement granite of Mohar structure. The studies reveal optical property aberrations of common rock forming minerals, viz., planar deformation, lowered birefringence and mosaics in quartz, toasting and ladder texture in alkali feldspar along with near-isotropism in bytownite, generally coinciding with some degree of structural/crystallographic deviations, as reflected by their Raman spectra and XRD data. Recent microRaman characterization of feldspar from this area (Roy et al. 2017) also clearly brings out the high degree of irregularity, implying structural damage in grains of PDF quartz and feldspars. In the present study, it is observed from the Raman spectral pattern that, multiplicity of peak groups, peak positions, and peak widths of $\alpha$ quartz and feldspars, vary subtly from their standard spectra. Also additional peaks are observed, viz., for the studied $\alpha$-quartz marked by multiple PDF-like structures, an extra peak is observed at $1300 \mathrm{~cm}^{-1}$ and for toasted orthoclase, small additional peaks are observed around 1300 and $1500 \mathrm{~cm}^{-1}$. For the nearly isotropic bytownite in the shocked mafic clast, the notable aberration includes peak broadening around Raman shift of $700 \mathrm{~cm}^{-1}$ and development of a peak at $1300 \mathrm{~cm}^{-1}$. The partial isotropism of bytownite may be suggestive of a non-uniform transformation to glass-like material. Unlike maskelynite (glassy plagioclase), a prominent band broadening and a relative shift of the Raman band from 570 to $600 \mathrm{~cm}^{-1}$ is missing in this case. The XRD data indicates modifications in the unit cell parameter of quartz, alkali feldspar and plagioclase with decrease in cell volume. The inter-tetrahedral angle and $c_{0} / a_{0}$ of quartz suggest that the silica tetrahedral structure is not regular and that the inter-tetrahedral angle is in the range of $120^{\circ}-144^{0}$ implying bending of the Si$\mathrm{O}-\mathrm{Si}$ angle due to compression and initiation of severe distortion and amorphisation. When plotted in $\mathrm{c}_{0} / \mathrm{a}_{0}$ vs. $\mathrm{P}$ diagram (Angel et al. 1997), the four sample points do not signify significant pressure rise, but the optical presence of PDF-like 


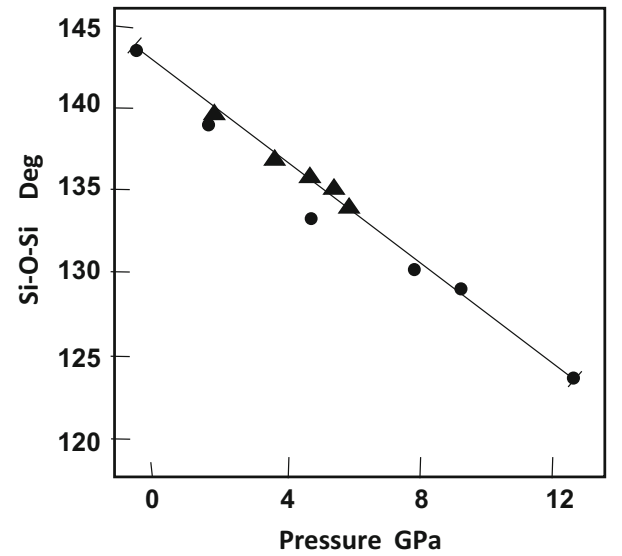

Figure 9. Si-O-Si angle vs. pressure diagram (Hazen et al. 1989). Dhala (Mohar) samples are represented by triangles.

structures in these quartz grains sets the pressure range to 8-25 GPa (French 1998). This apparent paradox may be due to the fact that the grains analyzed are possibly intermediate between perfectly crystalline and amorphous stage, occurring perhaps as a precursor prior to total amorphisation. Decompression during shock recovery may also be a cause for this observation. It is also possible that post-shock thermal effect might have caused annealing of shock damage, leaving planar microstructures unaffected (Grieve et al. 1996). Using $\mathrm{Si}-\mathrm{O}-\mathrm{Si}$ angle vs. pressure diagram (figure 9), the samples from Dhala (Mohar) structure would fall along the line obtained by Hazen et al. (1989), suggesting a pressure maxima of about 12 GPa.

Parisite, a calcium, light rare earth element fluorocarbonate, is a rare mineral and is reported from type geological setting of folded carbonaceous shale or in calcite/ankerite veins in hydrothermal deposits, where it is associated with carbonate (www.mindat.org; Gysi and William-Jones 2015). It is rarely reported from granitoids, although bastnaesite, a light rare earth element fluorocarbonate is reported from granitoid rocks. In the studied sample, it occurs as a rare accessory mineral, and is marked by striated nature, high relief, uniaxial positive nature and high birefringence and without any association of carbonate mineral. Parisite rarely occurs as single crystals and most specimens are 'polycrystals', syntaxic intergrowths of two species (Donnay and Donnay 1953). Micro Raman data brings out the fact that the crystals under study, although striated, have uniform composition and does not suggest intergrowth of closely related species. This data also shows deviation from the standard data, in having a sharp drop of
Raman shift from 300 to $400 \mathrm{~cm}^{-1}$ and absence of a gentle peak at $400 \mathrm{~cm}^{-1}$ as observed in the standard Raman spectral pattern. An additional small peak is observed in the sample around $670 \mathrm{~cm}^{-1}$. Considering all these, it appears that the parisite crystals within the basement granite, as confirmed by micro-Raman spectral pattern, suggest lattice aberration due to shock damage. Detailed characterisation of parisite by other techniques remain within the scope of future studies.

Thus, this preliminary finding brings to light the occurrence of the rare mineral, parisite, in the basement granite of Mohar and also qualitatively brings out the anomalous nature of quartz, alkali feldspar and bytownite in shocked basement granite and melt breccia, with respect to their optical, structural and crystallographic properties. The anomalous nature may be attributed to the various shock transformation in an established impact environment.

\section{Acknowledgements}

Authors are thankful to the Director, AMD for the permission to publish the paper. Analytical support provided by Dr Rajesh Sharma, Scientist ' $G$ ' of Wadia Institute of Himalayan Geology, Dehradun and Shri R Viswanathan, AMD, Hyderabad are acknowledged. The effort of the anonymous reviewers is appreciated for improving the quality of the paper.

\section{References}

Angel R J, Allan D R, Miletich R and Finger T W 1997 The use of quartz as an internal pressure standard in highpressure crystallography; J. Appl. Cryst. 30 461-466.

Basu A K 1986 Geology in parts of Bundelkhand granite massif, central India; Rec. Geol. Surv. India $\mathbf{1 1 7 ( 2 )} 61-$ 124 .

Bhattacharya D and Rao M K 2006 Lithogeochemical sampling and lithostructural mapping of Mohar Cauldron, Shivpuri district, M.P; Unpublished Annual Report of Field Season 2005-2006. Atomic Minerals Directorate for Exploration and Research, Northern Region, New Delhi.

Deer W A, Howie R A and Zussman J 2001 Rock-Forming Minerals, 4 A Framework Silicates - Feldspars; The Geological Society, London.

Deer W A, Howie R A, Wise W S and Zussman J 2004 Rock-Forming Minerals, $4 B$ Framework Silicates - Silica Minerals, Feldspathoids and Zeolites; The Geological Society, London.

Donnay G and Donnay J D H 1953 The crystallography of bastnaesite, parasite, roentgenite and synchisite; Am. Mineral. 38 932-963. 
French Bevan M 1998 Shock-metamorphic effects in rocks and minerals; In: Traces of Catastrophe: A Handbook of Shock-Metamorphic Effects in Terrestrial Meteorite Impact Structures; Lunar and Planetary Institute, 130p.

Grieve R A F, Langenhorst F and Stoffler D 1996 Shock metamorphism of quartz in nature and experiments: II. Significance in geoscience; Meteor. Planet. Sci. 31 6-35.

Gysi A P and William-Jones A E 2015 The thermodynamic properties of bastnaesite-(Ce) and parisite-(Ce); Chem. Geol. 392 87-101.

Hazen R M and Prewitt C T 1977 Linear compressibilities of low albite: High pressure structural implications; $\mathrm{Am}$. Mineral. 62 554-558.

Hazen R M, Finger L W, Hemley R J and Mao H K 1989 High pressure crystal chemistry and amorphisation of alpha quartz; Solid State Commun. 72(5) 507-511.

Huffman A R, Brown J M, Carter N and Reimold W U 1993 The microstructural response of quartz and feldspar under shock loading at variable temperatures; J. Geophys. Res. 98 22,171-22,197.

Jain S C, Gaur V P, Srivastava S K, Nambiar K V and Saxena H P 2001 Recent find of a cauldron structure in Bundelkhand craton; Geol. Surv. India Spec. Publ. 64 289-297.

Kingma K J, Hemley R J, Mao H K and Veblen D R 1993 New high pressure transformation in alpha quartz; Phys. Rev. Lett. 70 3927-3930.

Corresponding editor: Pulak Sengupta
Mondal M E A, Goswami J N, Deomurari M P and Sharma K $\mathrm{K} 2002$ Ion microprobe ${ }^{207} \mathrm{~Pb} /{ }^{206} \mathrm{~Pb}$ ages of zircons from the Bundelkhand massif, northern India: Implications for crustal evolution of the Bundelkhand Aravalli protocontinent; Precamb. Res. 117 85-100.

Pati J K 2005 The Dhala structure, Bundhelkhand craton, central India - A new large Paleoproterozoic impact structure; Meteorit. Planet Sci. 40 (Suppl.) A121.

Pati J K, Reimold W U, Koeberl C and Pati P 2008 The Dhala structure, Bundelkhand craton, Central India Eroded remnant of a large Paleoproterozoic impact structure; Meteor. Planet Sci. 43 1383-1398.

Roy M, Kumar S, Pandey P, Bhairam C L and Parihar P S 2014 Petrological evidences of impact-induced shock metamorphism in the basement granitoids and rhyolitic melt breccia of Mohar area, Shivpuri dist., M.P., India; J. Geol. Soc. India 84 377-384.

Roy M, Sengupta P, Mahadik P, Kumar S, Pandey P and Prihar P S 2016 Carbonate-silicate melt immiscibility in impact melt breccia from Mohar, Shivpuri district, Madhya Pradesh, India; Lunar Planet. Sci. XIVII, \#1887.

Roy M, Sengupta P, Mahadik P and Pandey P 2017 Raman signature of shocked feldspar, quartz and glassy patches from impact rocks of Mohar; Lunar Planet. Sci. XLVIII \#1209.

Somayazulu M, Sharma S and Sikka S K 1994 On the structure of the new high pressure phase in alpha quartz; Phys. Rev. 73 98-101. 